\title{
THE EXAMINATION OF FACTORS INFLUENCING STUDENTS TOWARD CHOOSING HOSPITALITY AS A MAJOR; THE CASE OF UNDERGRADUATE HOSPITALITY STUDENTS
}

\begin{abstract}
Ali A. Alalmai ${ }^{1}$
Abstract: This research examines the factors that influence students' choice to major in hospitality management. Furthermore, this research assessed the role of student personality type in the academic major selection process. Data were collected from 152 undergraduate hospitality majors attending a single public university, and personality type was assessed using the Self-Directed Search based. The results may help hospitality management programs tailor recruitment materials to engage naturally entrepreneurial and outgoing potential students. The results will also help potential students discern career paths that may be most rewarding given their natural personality strengths.
\end{abstract}

Key words: Hospitality management, Education, Self-directed search, major choice, Holland, Chapman.

\section{INTRODUCTION}

Hospitality is one of the largest employers in countries around the world and in the U.S. alone the industry added 312,000 jobs in 2015 (U.S. Bureau of Labor Statistics, 2016). The old stereotype of hospitality jobs as low-wage, entry-level positions with little opportunity for advancement is increasingly outdated as skilled and educated people are becoming aware of hospitality career opportunities (U.S. Bureau of Labor Statistics, 2015).

The increased importance of the hospitality industry has led to new advanced technology, more consumer choice, and rising competition among firms (Goodman \& Sprague, 1991). Increased complexity brings the challenge of maintaining a skilled and qualified workforce that can keep up with all of the new trends.

With soaring demand for hospitality employees and limited supply of skilled personnel, demand for undergraduate and graduate hospitality programs has grown significantly. In fact, hospitality management programs doubled between 1992 and 2002 (Johanson, Ghiselli, Shea, \& Roberts, 2010).

\footnotetext{
${ }^{1}$ Assistant Professor, Department of Administration, Faculty of Community College,Jazan University,Jazan, Saudi Arabia.
} 
Barrows and Johan (2008) argued that the growth does not rely on a single factor, however it does appear that the growth in hospitality education parallels with industry trends. The good news for hospitality education programs is students in hospitality and lodging who have a college degree can expect better job opportunities than those without a degree (Canon \& Gascon, 2012; Montmarquette, Cannings, \&Mahseredjian, 2002; U.S. Bureau of Labor Statistics, 2015).

\section{LITERATURE REVIEW}

Many college students expect to enhance their career potential by acquiring the skills important to future employers (Canon \& Gascon, 2012; Montmarquette, Cannings, \& Mahseredjian, 2002). Students who pursue post-secondary education, especially in service fields such as hospitality, acquire unique skills not shared by those who do not pursue higher education, including leadership, communication, work experience, ability to prioritize work, ethics, business, nutrition and food safety knowledge (Kay \& Russette, 2000). College educated workers have higher salaries and savings, leading to more productivity overall (Baum \&Payea, 2005). In general, college students tend to have better personal lives including their overall health and longevity (Baum \& Payea, 2005; Canon \& Gascon, 2012).

A college degree in hospitality management contributes to the later success of managers in the hospitality industry (Goldmon, 2011). Those with a college degree have higher salaries and more promotions than those who lack the credential (Goldmon, 2011). Given the numerous advantages of college education, students naturally expend considerable effort choosing where to attend college and what subjects to study. This study sought to understand the decision process of those majoring in hospitality management. The theoretical framework of this study was based in Chapman's (1981) Model of Student College Choice variables and Holland's (1997) Theory of VocationalChoice.

Chapman's (1981) Model of Student School Choice has been a valuable tool to understand factors that influence student's selection of colleges. The model comprises variables related to external influences and student characteristics and expectations of college life. Recently, Bobbitt (2006) approved Chapman's model and argued that the model could bring a positive change to the hospitality management recruitment process.

Numerous research studies have been conducted using Holland's (1959) Theory of Vocational Choice, especially in nonacademic settings. However, some studies applied this theory to understand people's behavior toward choosing career or 
major. Holland's (1959) Theory of Vocational Choice is an interactive model based on a typology of persons and environments, and has several factors which influence career choices: (a) family; (b) peers, teachers, and other adult role models; (c) school, work, and leisure experiences; and (d) socioeconomic status and ethnic background.

In summary, many studies have investigated the factors that influence college students' major selection but few have examined the hospitality industry specifically. The few hospitality studies that exist demonstrate that career opportunities, social status, and encouragement from family and friends are highly influential for students who choose to pursue hospitality degrees. This data can help hospitality professionals and educators develop appropriate academic goals and curricula to engage students, as well as effectively market hospitality programs to increase student enrollment.

\section{METHODOLOGY}

\section{Research design}

This quantitative study was non-experimental and utilized a descriptivecorrelational research design. According to Fraenkel and Wallen (2006), "A major purpose of correlational research is to clarify our understanding of important phenomena by identifying relationships among variables" (p. 336). The phenomena assessed in this study were factors associated with how students selected an academic major. Student characteristics, external influences, and personality type data were collected using a descriptive questionnaire adapted from Wildman (1997). Personality type data were collected using the Self-Directed Search (SDS) Form R 5th Edition (Holland, 1997).

\section{Population and sample}

The population for this study was 297 undergraduate students at a large, public research university in the U.S. Data were collected from a final sample of 152 participants. All participants had selected hospitality as either an academic major or minor. All data were collected in Spring 2016. 


\section{Research questions}

The objective of this study was to examine the factors that lead college students to choose hospitality as a major. Furthermore, this research assessed the role of student personality type in the academic major selection process. Specifically, this study addressed the following research questions:

1. What are demographic characteristics of students majoring in hospitality?

2. What are the most frequent personality types among hospitality students?

3. What are the most frequent SDS three letter combinations among hospitality students?

4. What are the characteristics and background of students majoring in hospitality?

5. What are the external influences of students majoring in hospitality?

6. What is the relationship between personality type and external influences on hospitality students' selection of a college major?

\section{FINDING}

Participants in this study were predominantly White/non-Hispanic females, ages 2024, in their senior year of college, and considered in-state students. Nearly all participants had chosen hospitality as a major rather than a minor, and Hospitality Management was the intended or current academic track for over half of the participants. (Table 1)

Table 1: Demographic

\begin{tabular}{|l|c|c|}
\hline Variable & $F$ & $(\%)$ \\
\hline Gender & 108 & \\
$\quad$ Female & 44 & 70.1 \\
$\quad$ Male & 139 & 28.9 \\
\hline State Residence & 91.4 \\
In-state & 13 & 8.6 \\
$\quad$ Out-of-state & 72 & \\
\hline Class Standing & 56 & 47.4 \\
Senior & 20 & 36.8 \\
Junior & 4 & 13.2 \\
Sophomore & & 2.6 \\
Freshman & 119 & \\
\hline Ethnicity & 23 & 78.3 \\
White/non-Hispanic & 8 & 15.1 \\
Hispanic & 2 & 5.3 \\
Black/African-American & & 1.3 \\
Asian/Pacific Islander &
\end{tabular}




\begin{tabular}{|l|c|c|}
\hline Academic Program & 131 & 86.2 \\
Major & 21 & 13.8 \\
Minor & 85 & \\
\hline Track & 28 & 55.9 \\
Hospitality Management & 26 & 18.4 \\
Lodging & 12 & 17.1 \\
Food and Beverage & 1 & 7.9 \\
Wine & .7 \\
Education & & \\
\hline
\end{tabular}

Most participants did not have an immediate family association with hospitality. Nevertheless, half of the participants had worked in a restaurant in high school, although about one-third had no prior hospitality work experience. However, many students were involved in multiple extracurricular activities in high school, such as athletics, school electives, National Honor Society, and student government. Interestingly, most were not enrolled in a hospitality program in high school. Nearly half of the participants indicated that they chose to attend the university in the 12th grade, and the majority reported selecting their major after college matriculation. Given these data, it is unsurprising that nearly all students were aware of job opportunities in the hospitality industry while in high school, yet few were also aware of various hospitality majors offered at their university of choice or long-term hospitality career opportunities. 
Table 2: Characteristics and Background of Hospitality Students

\begin{tabular}{|l|c|c|}
\hline Variable & $F$ & $(\%)$ \\
\hline Family association with & 119 & 78.3 \\
hospitality & 33 & 21.7 \\
No & & \\
Yes & 75 & \\
\hline Hospitality work experience & 51 & 49.3 \\
Restaurant & 19 & 33.6 \\
No hospitality work & 4 & 12.5 \\
experience & 3 & 2.6 \\
Other hospitality experience & & 2 \\
Lodging & 13 & \\
Theme parks & 9 & 8.6 \\
\hline College decision year & 14 & 5.9 \\
$9^{\text {th }}$ grade or below & 74 & 9.2 \\
$10^{\text {th }}$ grade & 42 & 48.7 \\
$11^{\text {th }}$ grade & & 27.6 \\
$12^{\text {th }}$ grade & 7 & 4.6 \\
After high school & 7 & 4.6 \\
\hline Major decision year & 4 & 2.6 \\
$9^{\text {th }}$ grade or below & 35 & 23 \\
$10^{\text {th }}$ grade & 99 & 65.1 \\
$11^{\text {th }}$ grade & & \\
$12^{\text {th }}$ grade & 55 & 36.2 \\
After high school & 97 & 63.8 \\
\hline Aware of career opportunity & & \\
Yes & & 95.4 \\
No & & 4.6 \\
\hline Aware of job opportunity & & \\
Yes & & \\
No & & \\
\hline
\end{tabular}

Using Holland's $(1959,1997)$ RIASEC model, the most common personality type was Enterprising, followed closely by Social. Specifically, the most common combinations (in descending order of frequency) were Enterprising-SocialConventional, Enterprising-Conventional-Social, and Enterprising-Social-Artistic. 
Table 3: Personality Type Rank

\begin{tabular}{|r|c|c|c|c|c|c|}
\hline & \multicolumn{2}{|c|}{ First Code } & \multicolumn{2}{c|}{ Second Code } & \multicolumn{2}{c|}{ Third Code } \\
\hline Personality Type & $F$ & $(\%)$ & $F$ & $(\%)$ & $F$ & $(\%)$ \\
\hline Realistic & 6 & 3.9 & 15 & 9.9 & 15 & 9.9 \\
\hline Investigative & 7 & 4.6 & 9 & 5.9 & 11 & 7.2 \\
\hline Artistic & 8 & 5.3 & 15 & 9.9 & 25 & 16.4 \\
\hline Social & 34 & 22.4 & 56 & 36.8 & 36 & 23.7 \\
\hline Enterprising & 87 & 57.2 & 34 & 22.4 & 16 & 10.5 \\
\hline Conventional & 10 & 6.6 & 23 & 15.1 & 49 & 32.2 \\
\hline Total & 152 & 100 & 152 & 100 & 152 & 100 \\
\hline
\end{tabular}

Table 4: Most Common Three-Letter Codes

\begin{tabular}{|r|c|c|}
\hline Codes & $F$ & $(\%)$ \\
\hline ESC & 26 & 17.1 \\
\hline ECS & 12 & 7.9 \\
\hline ESA & 8 & 5.3 \\
\hline
\end{tabular}

Three categories of external influences were studied: prior exposure to hospitality, people of influence, and hospitality department factors. Overall, the six external factors considered most influential by hospitality students in their college major selection were atmosphere in the hospitality department, faculty friendliness, teaching reputation of thehospitality department, parents or guardians, college friends, and high school visits from hospitality department representatives.

Table 5: External Influences of Students with Mean Scores Greater than 5.0

\begin{tabular}{|c|c|c|c|}
\hline External Influences & Rank & Mean & $S D$ \\
\hline Atmosphere in department $^{c}$ & 1 & 6.63 & 3.01 \\
\hline Faculty friendliness ${ }^{c}$ & 2 & 6.12 & 3.24 \\
\hline Teaching reputation ${ }^{\mathrm{c}}$ & 3 & 6.11 & 3.21 \\
\hline Parent or guardian ${ }^{b}$ & 4 & 6.03 & 2.99 \\
\hline Friend in college $^{b}$ & 5 & 5.23 & 3.23 \\
\hline High school visit from department representative ${ }^{c}$ & 6 & 5.19 & 3.60 \\
\hline
\end{tabular}

Finally, three significant relationships were found between SDS codes and external influences. Family and friends were positively associated with the first SDS code and the summary code. Professionals in the hospitality field were slightly negatively associated with the third SDS code. 


\section{SUMMARY AND CONCLUSION}

To address Research Question 1, demographic data were collected regarding gender, age, academic major, state residence, and ethnicity. The ratio of male to female participants in this study sample were quite dissimilar to the gender ratio found among the general student population. During the Spring 2016 semester, the undergraduate population was $44.9 \%$ female and $55.1 \%$ male (U.S. News and World Report, 2016). The sample in this study, in contrast, were $71.1 \%$ female and $28.9 \%$ male. Although this limits the generalizability of the results, previous studies found that male and female students are both motivated by culture, social factors, type of work, and physical working conditions (Alananzeh, 2014; Chellen\&Nunkoo, 2010). Those factors significantly influence the type of program students choose. These results are valuable because the percentage of females in the entering classes of the major U.S. hospitality programs continues to grow (Sigala\& Baum, 2003).

At the large public university, the average student age was 21 years old (U.S News and World Report, 2016). The most common age of students in this study was 22 years old, and $90 \%$ of the sample was between the ages of 20-24 years old. The majority of students were in-state residents, and only 13 participants were out-ofstate residents. This distribution reflects enrollment trends at the large public university; $92 \%$ of the entire student population are in-state residents (U.S. News and World Report, 2016). About $75 \%$ of students were self- reported residents of large metropolitan areas, although the definition of metropolitan area and small city/town were self-defined.

According to Holland (1997), ethnicity is one factor that influences academic major choice. Nearly $80 \%$ of participants considered themselves White/non-Hispanic, and $15 \%$ considered themselves Hispanic. Eight students (5.3\%) identified as Black/African-American and two (1.3\%) identified as Asian/Pacific Islander. Although the percentage of White students seems especially high, this distribution should not be alarming given that $79.7 \%$ of the state population is White, and most students are in-state residents (U.S. Census Bureau, 2015).

Almost all participants chose hospitality as a major; only $21(13.8 \%)$ chose it as a minor. The university incorporates tracks into its curriculum and the most common academic track for students was Hospitality Management (55.9\%), followed by Lodging (18.4\%), Food and Beverage $(17.1 \%$,), and Wine $(7.9 \%)$. Only one student planned to go into Education $(0.7 \%)$. 
To address Research Questions 2-3, personality type was measured using the SelfDirected Search (SDS) created by Holland (1997), based on the RIASEC model. Among the 152 hospitality students in this study, the three most dominant personality types were Enterprising (57.2\%), Social (36.8\%), and Conventional (32.2\%). The SDS instrument measures individual personality as a three-letter combination of the six possible codes. According to Holland (1997), hospitality administration/management is categorized under ESR, a code quite similar to the top three types found in this study. The three most dominant personality types were ESC (17.1\%), ECS (7.9\%), and ESA (5.3\%).

These findings support previous studies of personality type and vocational interest. In 1991, Chacko reported that student interests were predictive of eventual career choice. On the RIASEC model, hotel/restaurant managers were most likely to be Enterprising (Chacko, 1991). Hospitality majors in general were interested in status and leadership more than intellectually challenging pursuits such as scientific research (Chacko, 1991).

To address Research Question 4, the majority of students (49.3\%) reported having had restaurant experience, but $33.6 \%$. reported no hospitality work experience. It was unclear if they held non-hospitality employment during high school. Huang and Lo (2014) found that work experience can encourage students to pursue hospitality careers. Almost all participants reported involvement in some type of high school activities, clubs, or organizations. The five most frequently reported high school activities by hospitality students were athletics (23.3\%), school electives (16.9\%), National Honor Society (12.7\%), student council or government (11.5\%), and cheerleading or spirit squad (9.5\%).

To address Research Question 5, data were collected regarding external influences on participants' choice of academic major. Not surprisingly, the Internet was the most influential source of prior exposure to the hospitality major, followed by television programs. The most influential people were parents and guardians, followed by friends in college. This supports previous findings from numerous studies that parents and friends have significant influence on students' major choice (Alananzeh, 2014; Chapman, 1981; Holland, 1997; Zahari et al. 2005). Chapman (1981) stated that students prefer being around other students of similar aptitude as theirs. Also, Chapman (1981) argued that parental influence increases as academic performance improves, which then influences the student's choice of college. Holland (1997) also found family and peers to impact school and vocation choice. 
The most influential college or departmental factors were the program's atmosphere, faculty friendliness, teaching reputation of professors, and high school visits from faculty in the department. Chapman (1981) argued that the fixed characteristics are a means to describe the college in the short term. That said, it is important to note that it might take a significant amount of time for a college to redefine itself and change the opinion of potential students.

In total, the most influential factors, in descending order of influence, were atmosphere in the hospitality department, faculty friendliness, teaching reputation of the department, parent or guardian, friends in college, and high school visit from department representatives. These results support Lehmann's (2015) recent findings concerning the influence of electronic word-of-mouth on the college search process. Given the ubiquity of social media, especially among Generation Y, Lehmann (2015) hypothesized that electronic influences would eclipse traditional word-ofmouth. Yet electronic word-of-mouth was actually less influential than traditional word-of-mouth when students were involved in the college search and choice process (Lehmann, 2015).

To address Research Question 6, Pearson product-moment correlation coefficients were calculated to identify possible relationships between personality typeand external influences. Family and friends were positively correlated with the first SDS code, Enterprising, and the summary code Enterprising-Social-Conventional. Professionals in the hospitality field were slightly negatively associated with the third SDS code, Conventional. Vocational interest is extremely stable over time. Lucy (1976) reported substantial stability in Holland type "in spite of changing social and economic conditions" (p. 78). Therefore, external factors measured in this study are unlikely to affect the SDS codes. Rather, a student's personality type mediates which category of external factor influences their college major selection and the size of the effect. As mentioned earlier, most of the hospitality students in this study scored high on the Enterprising scale. Those who are Enterprising may actively seek input from close friends and relatives, and thus highly value these opinions. These influences were also significantly correlated with the overall summary code Enterprising-Social-Conventional. The influence of hospitality professionals seems to be valued most by students who scored lowest on the Conventional scale. Perhaps these students are going against the advice and wishes of family and friends, and are encouraged to pursue hospitality nevertheless by respected hospitality professionals. 


\section{REFERENCES}

1. Alananzeh, O. A. (2014). Exploring the factors influencing students in enrolling tourism and hospitality management colleges in Jordan: A case study in Aqaba economic zone. Journal of Management Research, 6(2), 6173.

2. Barrows, C. W., \& Johan, N. (2008). Hospitality management education. In R. C. Wood \& B. Brotherton (Eds.), The Sage handbook of hospitality management (pp. 146-162). Thousand Oaks, CA: Sage Publications.

3. Baum, S., \&Payea, K. (2005). Education pays 2004: The benefits of higher education for individuals and society. Trends in Higher Education Series. Washington, DC: College Entrance Examination Board.

4. Bobbitt, R. (2006). Factors influencing recruitment, retention, and placement in the college of agricultural sciences and natural resources. (Unpublished master's thesis). Texas Tech University, Lubbock, TX.

5. Canon, M. E., \&Gascon, C. S. (2012). College degrees: Why aren't more people making the investment? The Regional Economist, 5(1), 5-9.

6. Chacko, H. E. (1991). Can you pick out the accountant? Students' interests and career choices. Journal of Education for Business, 66(3), 151-154.

7. Chapman, D. W. (1981). A model of student college choice. The Journal of Higher Education, 52(5), 490-505.

8. Chellen, H., \&Nunkoo, R. (2010). Understanding students' commitment to employment in the tourism and hospitality industry. International Research Symposium in Service Management, 1-41.

9. Fraenkel, J.R., \&Wallen, N.E. (2006). How to design and evaluate research in education ( $6^{\text {th }}$ ed.). Boston, MA: McGraw Hill. from http://www.doleta.gov/brg/Indprof/Hospitality_profile.cfm

10. Goldmon, S. S. (2011). The role of higher education for successful managers in the hospitality industry (Doctoral dissertation). Available from ProQuest Dissertation and Theses database. (UMI No. 3477821)

11. Goodman, R. J., \& Sprague, L. G. (1991). The future of hospitality education: Meeting the industry's needs. The Cornell Hotel and RestaurantAdministration Quarterly, 32(2), 66-69.

12. Holland, J. L. (1959). A theory of vocational choice. Journal of Counseling Psychology, 6(1), 35.

13. Holland, J. L. (1997). Making vocational choices $\left(3^{\text {rd }}\right.$ ed.). Odessa, FL: Psychological Assessment Resources.

14. Johanson, M., Ghiselli, R., Shea, L. J., \& Roberts, C. (2010, July). Revealing key competencies of hospitality graduates demanded by industry: A 25-year review. July 31, 2010). Paper presented at the International 
CHRIE Conference, San Juan, Puerto Rico. Paper retrieved from http://scholarworks.umass.edu/refereed/CHRIE_2010/Saturday/5

15. Kay, C., \&Russette, J. (2000). Hospitality-management competencies: Identifying managers' essential skills. Cornell Hotel and Restaurant Administration Quarterly, 41(2), 52-63

16. Lehmann, W. S. (2015). The influence of electronic word-of-mouth (eWOM) on college search and choice (Doctoral dissertation). Open Access Dissertations.Paper 1378.

17. Lehmann, W. S. (2015). The influence of electronic word-of-mouth (eWOM) on college search and choice (Doctoral dissertation). Open Access Dissertations.Paper 1378.

18. Montmarquette, C., Cannings, K., \&Mahseredjian, S. (2002). How do young people choose college majors? Economics of Education Review, 21(6), 543-556.

19. Sigala, M., \& Baum, T. (2003). Trend and issue in tourism and hospitality higher education: Visioning the future. Tourism and Hospitality Research4(4), 367-376.

20. U.S. Bureau of Labor Statistics. (2015). Career guide to industries. Retrieved October 3, 2016

21. U.S. Bureau of Labor Statistics. (2016). Current employment statistics. Retrieved October 3, 2016 from www.bls.gov/ces/home.htm

22. U.S. Census Bureau. (2015). QuickFacts Texas. Retrieved October 8, 2016 from http://www.census.gov/quickfacts/table/PST045215/48

23. U.S. News and World Report. (2016). Texas Tech University. Retrieved October 8, 2016 from http://colleges.usnews.rankingsandreviews.com/bestcolleges/texas-tech-university-3644

24. Wildman, M. (1997). Factors in high school that influence choice of major by NMSU agriculture students (Unpublished master's thesis). New Mexico State University, Las Cruces, NM.

25. Zahari, M. S., Sharif, M. S., Ahmad, T., \& Ismail, T. (2005). A study of factors moderating students' selection of hospitality programme and subsequent career intentions. TEAM Journal of Hospitality \& Tourism, 1, $103-120$. 